\title{
Synthesis, Biological Activity and Cytotoxicity of New Fused Pyrazolo[1,5-a]pyrimidine from 5-Aminopyrazole Incorporated with $p$-Chloroaniline
}

\author{
Wedad Melad Al-Adiwish ${ }^{1,}$, , Fatma Ali Shtewi ${ }^{1}$, Munira Muftah Ashrif ${ }^{1}$, Dalal Mohamed Ibrahim ${ }^{2}$ \\ ${ }^{1}$ Chemistry Department, Faculty of Science, Azawia University, Az Zawiyah, Libya \\ ${ }^{2}$ Chemistry Department, Faculty of Science, Omar Al-mukhtar University, Al Bayda, Libya
}

Email address:

wedad8073@yahoo.com (W. M. Al-Adiwish)

${ }^{*}$ Corresponding author

\section{To cite this article:}

Wedad Melad Al-Adiwish, Fatma Ali Shtewi, Munira Muftah Ashrif, Dalal Mohamed Ibrahim. Synthesis, Biological Activity and Cytotoxicity of New Fused Pyrazolo[1,5-a]pyrimidine from 5-Aminopyrazole Incorporated with $p$-Chloroaniline. American Journal of Heterocyclic Chemistry. Vol. 3, No. 6, 2017, pp. 86-94. doi: 10.11648/j.ajhc.20170306.15

Received: October 28, 2017; Accepted: December 8, 2017; Published: January 8, 2018

\begin{abstract}
Amino-3-(4-chlorophenylamino)-1H-pyrazole-4-carbonitrile 3 was prepared in high yield from the reaction of hydrazine hydrate with known 2-[(4-chlorophenylamino)(methylthio)methylene]malononitrile 2a (which was prepared from reaction of 2-[bis(methylthio)methylene]malononitrile 1 with $p$-Chloroaniline) under reflux in ethanol. The compound 3 was utilized as a key intermediate for the synthesis of pyrazolo[1,5-a]pyrimidines 4a-b, 5a-c and 6 by reactions with some of ketene- $S, S$-and $N$, $S$-acetals. The antibacterial and antifungal activities, as well cytotoxicity against Breast cancer cells (MCF7) of some selected compounds are also reported.
\end{abstract}

Keywords: $p$-Chloroaniline, 5-aminopyrazole, Pyrazolo[1, 5-a]pyrimidines, Antibacterial Activity, Antifungal Activity, Cytotoxicity

\section{Introduction}

Pyrazolopyrimidine derivatives constitute an interesting class of heterocycles because of their synthetic versatility, effective biological activities, and pharmacological importance as purine analogs [1-5]. Various related compounds of pyrazolopyrimidines have antitumor and antileukemic activities [6, 7]. Several derivatives such as 4hydroxypyrazolopyrimidine (allopurin), which are used in the treatment of hyperuricemia and gout, inhibit de novo purine biosynthesis and xanthine oxidase [8]. Cyclization of 5 -aminopyrazoles with ketene- $S, S$ and $N, S$-acetals is the most widely used route for the synthesis of pyrazolopyrimidines [9-12]. Accordingly, we report in this paper novel synthesis of functionalized pyrazolo $[1,5-a]$ pyrimidines $4 \mathrm{a}-\mathrm{b}, 5 \mathrm{a}-\mathrm{c}, 6$ by the reactions of 5-aminopyrazole 3 with respective 2 -[bis (methylthio)methylene]malononitrile 1, ethyl 2-cyano-3,3bis[methylthio]acrylate, $\alpha, \alpha$-dicyanoketene- $N, S$-acetals 2 ac. The antibacterial, antifungal, cytotoxicity testing results of some selected compounds is also included.

\section{Materials and Methods}

\subsection{Chemistry}

All melting points were determined using a hot stage Gallenkamp melting point apparatus. Infrared spectra were recorded from $\mathrm{KBr}$ discs on FT-IR 8300 Shimadzu spectrometer. ${ }^{1} \mathrm{H}$ NMR and ${ }^{13} \mathrm{C}$ NMR spectra were recorded on FT-NMR $400 \mathrm{MHz}$ Joel, ECP and FT-NMR $600 \mathrm{MHz}$ Bruker, AVANCE III spectrometer operating at $400 \mathrm{MHz}$, and $600 \mathrm{MHz}$ for ${ }^{1} \mathrm{H} \mathrm{NMR}$ and at $100 \mathrm{MHz}, 150 \mathrm{MHz}$ for ${ }^{13} \mathrm{C}$ NMR in DMSO- $d_{6}$ as solvent and using TMS as internal standard. DIMS spectra were recorded on QP5050A Shimadzu apparatus. X-ray diffraction (XR-D) data were collected at room temperature with Bruker APEXII CCD a spectrometer. General purpose silica gel of Merck No. 5545 with UV indicator were used in TLC experiments to monitor completion of reactions, in which DCM was used as eluent. 


\subsubsection{Synthesis of 2-[(4-Chloropzhenylamino) (Methylthio) Methylene] Malononitrile (2a)}

A mixture of 2-[bis (methylthio) methylene]malononitril 1 $(1.7 \mathrm{~g}, 0.01 \mathrm{~mol}), p$-chloroaniline $(1.27 \mathrm{~g}, 0.01 \mathrm{~mol})$, and three drops of triethylamine (TEA) was refluxed in absolute ethanol $30 \mathrm{~mL}$ on oil-bath in the presence balloon of nitrogen. The reaction mixture was refluxed for one week. The solvent was evaporated and the product was collected, washed with ethanol, dried and recrystallized from ethanol to give pure 2-[(4chlorophenylamino)(methylthio)methylene]malononitrile 2a.

Yield, 48\%; colorless crystals; mp $165-167^{\circ} \mathrm{C}$; FT-IR $\left(\mathrm{KBr}, \mathrm{cm}^{-1}\right)$ v: $3246(\mathrm{NH}-\mathrm{Ar}), 3010(\mathrm{H}-\mathrm{Ar}), 2200,2189$ $(2 \mathrm{CN}), 1585,1526,1500(\mathrm{C}=\mathrm{C} / \mathrm{C}=\mathrm{N}) ;{ }^{1} \mathrm{H}$ NMR $(400 \mathrm{MHz}$, DMSO- $\left.d_{6}\right) \delta: 2.50\left(\mathrm{~s}, 3 \mathrm{H}, \mathrm{SCH}_{3}\right), 7.34(\mathrm{~d}, 2 \mathrm{H}, 2 \mathrm{H}-\mathrm{Ar}$, $J=8.04), 7.49$ (d, 2H, 2H-Ar, $J=8.04), 10.58$ (s, 1H, NH-Ar); ${ }^{13} \mathrm{C}$ NMR $\left(100 \mathrm{MHz}\right.$, DMSO- $\left.d_{6}\right) \delta: 16.4\left(\mathrm{SCH}_{3}\right), 53.9$ (C-2CN), $116.9(2 \mathrm{CN}), 126.2(2 \mathrm{C}-\mathrm{H}, \mathrm{Ar}), 129.7(2 \mathrm{C}-\mathrm{H}$, Ar), $131.2(\mathrm{C}-\mathrm{Cl}), 137.9$ (C-NH, Ar), 172.4 (S-C-NH).

\subsubsection{Synthesis of 5-amino-3-(4-Chlorophenylamino)-1H- Pyrazole-4-Carbonitrile (3)}

A mixture of 2-[(4-chlorophenylamino)(methylthio) methylene]malononitrile $2 \mathrm{a}(0.998,4 \mathrm{mmol})$ and hydrazine hydrate $(1.00 \mathrm{~g}, 20 \mathrm{mmol})$ was refluxed on water-bath for 2 hours. Then, $20 \mathrm{~mL}$ of ethanol was added, and the reaction mixture was refluxed for further 2 hours. The solvent was evaporated and the product was collected, washed with ethanol, dried and recrystallized from methanol to give pure product 3.

Yield, 97\%; whit solid; mp $240-242^{\circ} \mathrm{C}$; FT-IR $\left(\mathrm{KBr}, \mathrm{cm}^{-1}\right)$ $v: 3430,3254\left(\mathrm{NH}_{2} / \mathrm{NH}-\mathrm{Ar}\right), 2915(\mathrm{H}-\mathrm{Ar}), 2212(\mathrm{CN})$, 1622, 1611, $1584(\mathrm{C}=\mathrm{C} / \mathrm{C}=\mathrm{N})$; ${ }^{1} \mathrm{H}$ NMR $(400 \mathrm{MHz}, \mathrm{DMSO}-$ $\left.d_{6}\right) \delta: 6.30\left(\mathrm{~s}, 2 \mathrm{H}, \mathrm{NH}_{2}\right.$, pyrazole), $7.20(\mathrm{~d}, 2 \mathrm{H}, 2 \mathrm{H}-\mathrm{Ar}, J=8.8$ $\mathrm{Hz}), 7.50(\mathrm{~d}, 2 \mathrm{H}, 2 \mathrm{H}-\mathrm{Ar}, J=8.8 \mathrm{~Hz}), 8.54(\mathrm{~s}, 1 \mathrm{H}, \mathrm{NH}$, pyrazole), 11.19 (s, 1H, NH-Ar); ${ }^{13} \mathrm{C}$ NMR $(100 \mathrm{MHz}$, DMSO- $\left.d_{6}\right) \delta: 63.6(\mathrm{C}-\mathrm{CN}), 115.7(\mathrm{CN}), 118.2(2 \mathrm{C}=\mathrm{H}, \mathrm{Ar})$, $122.9(\mathrm{C}-\mathrm{Cl}), 128.8(2 \mathrm{C}=\mathrm{H}, \mathrm{Ar}), 142.2(\mathrm{C}-\mathrm{NH}, \mathrm{Ar}), 151.2$ $(\mathrm{NH}-\mathrm{C}-\mathrm{N}), 153.5\left(\mathrm{C}-\mathrm{NH}_{2}\right)$.

\subsubsection{General Procedure for the Preparation of Pyrazolo $[1,5-a]$ Pyrimidines 4a-b}

Pyrazolo $[1,5-a]$ pyrimidines $4 \mathrm{a}-\mathrm{b}$ were prepared according to the literature procedure [14] as follows: To a solution of 5-aminopyrazole $3(4 \mathrm{mmol})$ in absolute ethanol (20 mL), 2-[bis (methylthio) methylene] malononitril (0.864 g; $4 \mathrm{mmol}$ ) or ethyl 2-cyano-3, 3-bis[methylthio]acrylate $(0.434 \mathrm{~g} ; 2 \mathrm{mmol})$, and three drops of triethylamine were added. The reaction mixture was refluxed for $5 \mathrm{~h}$. The resulting precipitate was filtered off, dried and crystallized from $\mathrm{EtOH}-\mathrm{DMF}$ to give pure products $4 \mathrm{a}-\mathrm{b}$.

\section{i. 5-amino-2-(4-chlorophenylamino)-7-(methylthio) pyrazolo [1, 5-a] pyrimidine-3, 6-dicarbonitrile (4a)}

Yield, $48 \%$; yellow solid; $\mathrm{mp}>300^{\circ} \mathrm{C}$; IR $\left(\mathrm{KBr}, \mathrm{cm}^{-1}\right) v$ : $3582,3513\left(\mathrm{NH}_{2} / \mathrm{NH}-\mathrm{Ar}\right.$ ), $3116(\mathrm{CH}-\mathrm{Ar}), 2212(\mathrm{CN}), 1649$, 1614, 1595, $1562(\mathrm{C}=\mathrm{C} / \mathrm{C}=\mathrm{N})$; ${ }^{1} \mathrm{H}$ NMR $(400 \mathrm{MHz}$, DMSO$\left.d_{6}\right) \delta: 2.50\left(\mathrm{~s}, 3 \mathrm{H}, \mathrm{SCH}_{3}\right), 7.34(\mathrm{~d}, 2 \mathrm{H}, \mathrm{Ar}, J=9.5 \mathrm{~Hz}), 7.69$ (d, $2 \mathrm{H}, \mathrm{Ar}), J=9.5 \mathrm{~Hz}), 7.83$ (br, $\left.2 \mathrm{H}, \mathrm{NH}_{2}\right), 9.60(\mathrm{~s}, 1 \mathrm{H}, \mathrm{NH}-$
$\mathrm{Ar}) ;{ }^{13} \mathrm{C}$ NMR $\left(100 \mathrm{MHz}, \mathrm{DMSO}-d_{6}\right) \delta: 16.9\left(\mathrm{SCH}_{3}\right), 67.1$ $(\mathrm{C}-\mathrm{CN}), 84.3(\mathrm{C}-\mathrm{CN}), 114.0,114.8(2 \mathrm{CN}), 120.2(2 \mathrm{CH}=$, Ar), $125.6(\mathrm{C}-\mathrm{Cl}), 129.1(2 \mathrm{CH}=, \mathrm{Ar}), 139.9(=\mathrm{C}-\mathrm{NH}), 152.5$ $(\mathrm{N}-\mathrm{C}-\mathrm{N}=), \quad 154.2 \quad(\mathrm{~N}-\mathrm{C}-\mathrm{NH}), \quad 155.9 \quad\left(\mathrm{C}-\mathrm{NH}_{2}\right), \quad 157.9$ (N-C-S); DIMS found $m / z$ : 355.10 (calc. for $\mathrm{C}_{15} \mathrm{H}_{10} \mathrm{ClN}_{7} \mathrm{~S}$ $\mathrm{M}^{+}$requires 355.80 ).

\section{ii. 2-(4-chlorophenylamino)-5-hydroxy-7-(methylthio) pyrazolo [1, 5-a] pyrimidine-3, 6-dicarbonitrile (4b)}

Yield, 21\%; yellow solid; m.p: > 350; IR $\left(\mathrm{KBr}, \mathrm{cm}^{-1}\right) v$ : 3338, 3214, (OH, NH-Ar), 3148 (H-Ar), 2215 (CN), 1598, $1580(\mathrm{C}=\mathrm{C} / \mathrm{C}=\mathrm{N}) ;{ }^{1} \mathrm{H}$ NMR $\left(600 \mathrm{MHz}, \mathrm{DMSO}-d_{6}\right) \delta: 2.80$ $\left(\mathrm{s}, 3 \mathrm{H}, \mathrm{SCH}_{3}\right), 7.30$ (d, 2H, Ar, J=9.0 Hz), 7.69 (d, 2H, Ar, $J=9.0 \mathrm{~Hz}), 9.18(\mathrm{~s}, 1 \mathrm{H}, \mathrm{NH}), 11.50(\mathrm{~s}, 1 \mathrm{H}, \mathrm{OH}) ;{ }^{13} \mathrm{C}$ NMR $\left(150 \mathrm{MHz}, \mathrm{DMSO}-d_{6}\right) \delta: 16.5(\mathrm{SMe}), 63.4(\mathrm{C}-\mathrm{CN}), 93.0$ $(\mathrm{C}-\mathrm{CN}), 115.5,117.7(2 \mathrm{CN}), 119.6(2 \mathrm{CH}=, \mathrm{Ar}), 124.5$ $(\mathrm{C}-\mathrm{Cl}), 128.9(2 \mathrm{CH}=, \mathrm{Ar}), 140.6(\mathrm{C}-\mathrm{NH}, \mathrm{Ar}), 151.0$ $(\mathrm{N}-\mathrm{C}-\mathrm{N}), \quad 155.0 \quad(\mathrm{~N}-\mathrm{C}-\mathrm{NH}), \quad 155.4 \quad\left(\mathrm{C}-\mathrm{SH}_{3}\right), \quad 162.7$ (C-OH); DIMS found $m / z$ : 356.25 (calc. for $\mathrm{C}_{15} \mathrm{H}_{9} \mathrm{ClN}_{6} \mathrm{OS}$, $\mathrm{M}^{+}$requires 356.02).

\subsubsection{Synthesis of pyrazolo [1, 5-a] pyrimidines $5 a-c$}

Pyrazolo $[1,5-a]$ pyrimidines 5a-c were prepared according to the literature procedure [14] as follows: 5-aminopyrazole 3 $(0.467 \mathrm{~g}, 2 \mathrm{mmol})$ was reacted respectively with 2-[(4chlorophenylamino) (methylthio) methylene] malononitrile 2 (0.490 g; $2 \mathrm{mmol}), 2$-[methylthio (morpholino) methylene] malononitrile $(0.420 \mathrm{~g} ; 4 \mathrm{mmol})$, and 2-[methylthio (piperidin-1-yl) methylene] malononitrile $(0.410 \mathrm{~g} ; 4 \mathrm{mmol})$, in absolute ethanol $(20 \mathrm{~mL})$, and three drops of triethylamine were added. The reaction mixture was refluxed for $48 \mathrm{~h}$. The resulting precipitate was filtered off, dried and crystallized from EtOH-DMF to give pure products 5a-c.

\section{i. 5-amino-2, 7-bis (4-chlorophenylamino) pyrazolo [1, 5-a] pyrimidine-3, 6-dicarbonitrile (5a)}

Yield, $23 \%$; Yellow solid; $\mathrm{mp}>350^{\circ} \mathrm{C}$; IR $\left(\mathrm{KBr}, \mathrm{cm}^{-1}\right) v$ : 3460, $3322\left(\mathrm{NH}_{2} / \mathrm{NH}-\mathrm{Ar}\right), 3116(\mathrm{H}-\mathrm{Ar}), 2204(\mathrm{CN}), 1644$, 1627, $1594(\mathrm{C}=\mathrm{C} / \mathrm{C}=\mathrm{N}) ;{ }^{1} \mathrm{H}$ NMR $\left(600 \mathrm{MHz}, \mathrm{DMSO}-d_{6}\right)$, 2.73 (s, 3H, $\left.\mathrm{NCH}_{3}, \mathrm{DMF}\right), 2.89$ (s, $\left.3 \mathrm{H}, \mathrm{NCH}_{3}, \mathrm{DMF}\right), 7.24$ (d, $2 \mathrm{H}, \mathrm{Ar}, J=9 \mathrm{~Hz}), 7.46$ (d, 2H, Ar, $J=8.4 \mathrm{~Hz}), 7.50$ (s, $1 \mathrm{H}$, $\mathrm{NH}$, attached with oxygen in DMF), $7.52(\mathrm{~d}, 2 \mathrm{H}, \mathrm{Ar}, J=9$ $\mathrm{Hz}$ ), 7.82 (d, 2H, Ar, J=8.4 Hz), 7.95 (s, H, CH, DMF), 9.42 $(\mathrm{s}, 1 \mathrm{H}, \mathrm{NH}) ; 10.15(\mathrm{~s}, 1 \mathrm{H}, \mathrm{NH}) ;{ }^{13} \mathrm{C}$ NMR $(150 \mathrm{MHz}$, DMSO- $\left.d_{6}\right) \delta: 31.2\left(\mathrm{NCH}_{3}\right), 36.3\left(\mathrm{NCH}_{3}\right), 64.1(\mathrm{C}-\mathrm{CN}), 66.6$ $(\mathrm{C}-\mathrm{CN}), 114.5(2 \mathrm{CN}), 119.9(4 \mathrm{CH}, \mathrm{Ar}), 124.8(2 \mathrm{C}-\mathrm{Cl})$, $129.3(4 \mathrm{CH}, \mathrm{Ar}), 140.0(2 \mathrm{C}-\mathrm{NH}), 152.8(\mathrm{NH}-\mathrm{C}=\mathrm{N}), 154.8$ $(\mathrm{HN}-\mathrm{C}-\mathrm{N}), 160.7\left(\mathrm{C}-\mathrm{NH}_{2}\right), 162.8(\mathrm{H}-\mathrm{C}=\mathrm{O})$; DIMS found $m / z$ : 434.25 (calc. for $\mathrm{C}_{20} \mathrm{H}_{11} \mathrm{Cl}_{2} \mathrm{~N}_{8} \mathrm{M}^{+}$requires 434.27).

\section{ii. 5-amino-2-(4-chlorophenylamino)-7-morpholino pyrazolo[1,5-a]pyrimidine-3,6-dicarbonitrile (5b)}

Yield, $55 \%$; yellow solid; $\mathrm{mp}>321-322^{\circ} \mathrm{C}$; IR $\left(\mathrm{KBr}, \mathrm{cm}^{-1}\right)$ $v: 3462,3290,3183\left(\mathrm{NH} / \mathrm{NH}_{2}\right), 3055(\mathrm{H}-\mathrm{Ar}), 2224(\mathrm{CN})$, 1609, 1602, $1578(\mathrm{C}=\mathrm{C} / \mathrm{C}=\mathrm{N}) ;{ }^{1} \mathrm{H}$ NMR $(400 \mathrm{MHz}$, DMSO$\left.d_{6}\right) \delta: 1.73\left(\mathrm{br}, 4 \mathrm{H}, \mathrm{N}\left(\mathrm{CH}_{2}\right)_{2}\left(\mathrm{CH}_{2}\right)_{2} \mathrm{O}, J=4.5 \mathrm{~Hz}\right), 3.73(\mathrm{br}$, $\left.4 \mathrm{H}, \mathrm{N}\left(\mathrm{CH}_{2}\right)_{2}\left(\mathrm{CH}_{2}\right)_{2} \mathrm{O}, J=4.5 \mathrm{~Hz}\right), 7.32(\mathrm{~d}, 2 \mathrm{H}, \mathrm{Ar}, J=9.0$ $\mathrm{Hz}), 7.42$ (br, $2 \mathrm{H}, \mathrm{NH}_{2}$ ), 7.71 (d, 2H, Ar, J=9.0 Hz), 9.60 (s, 
$1 \mathrm{H}, \mathrm{NH}) ;{ }^{13} \mathrm{C}$ NMR $\left(100 \mathrm{MHz}, \mathrm{DMSO}-d_{6}\right) \delta: 26.5\left(\mathrm{O}\left(\mathrm{CH}_{2}\right)_{2}\right.$ $\left.\left(\mathrm{CH}_{2}\right)_{2} \mathrm{~N}\right), 51.8\left(\mathrm{O}\left(\mathrm{CH}_{2}\right)_{2}\left(\mathrm{CH}_{2}\right)_{2} \mathrm{~N}\right), 64.0(\mathrm{C}-\mathrm{CN}), 69.5$ $(\mathrm{C}-\mathrm{CN}), 114.1,116.1(2 \mathrm{CN}), 119.9(2 \mathrm{CH}, \mathrm{Ar}), 124.9(\mathrm{C}-\mathrm{Cl})$, 128.9 (2CH, Ar), $140.2(\mathrm{C}-\mathrm{NH}, \mathrm{Ar}), 152.1(\mathrm{NH}-\mathrm{C}-\mathrm{N})$, $154.8\left(\mathrm{C}-\mathrm{NH}_{2}\right), 160.7(\mathrm{C}=\mathrm{C}-\mathrm{N})$. DIMS found $m / z: 394.15$ (calc. for $\mathrm{C}_{18} \mathrm{H}_{15} \mathrm{ClN}_{8} \mathrm{O} \mathrm{M}$ requires 394.11).

\section{iii. 5-amino-2-(4-chlorophenylamino)-7-(piperidin-1-yl)} pyrazolo [1, 5-a] pyrimidine-3, 6-dicarbonitrile (5c)

Yield, 21\%; white solid; m.p: 282 decompose; IR (KBr, $\mathrm{cm}^{-1}$ ) v: 3468, 3321, (NH-Ar, $\left.\mathrm{NH}_{2}\right), 3119(\mathrm{H}-\mathrm{Ar}), 2203$ $(\mathrm{CN}), 1649,1594,1562(\mathrm{C}=\mathrm{C} / \mathrm{C}=\mathrm{N}) ;{ }^{1} \mathrm{H}$ NMR $(400 \mathrm{MHz}$, DMSO- $\left.d_{6}\right) \delta: 2.49$ (br, $\left.4 \mathrm{H}, \mathrm{N}\left(\mathrm{CH}_{2}\right)_{2}\left(\mathrm{CH}_{2}\right)_{2} \mathrm{CH}_{2}\right), 3.65$ (br, $\left.\left.4 \mathrm{H}, \mathrm{N}\left(\mathrm{CH}_{2}\right)_{2}\left(\mathrm{CH}_{2}\right)_{2} \mathrm{CH}_{2}\right),\right), 3.44$ (br, $4 \mathrm{H}, \mathrm{N}\left(\mathrm{CH}_{2}\right)_{2}\left(\mathrm{CH}_{2}\right)$ $\left.{ }_{2} \mathrm{CH}_{2}\right), 7.01\left(\mathrm{~s}, 2 \mathrm{H}, \mathrm{NH}_{2}\right), 7.32(\mathrm{~d}, 2 \mathrm{H}, 2 \mathrm{CH}=, \mathrm{Ar}, J=9.2 \mathrm{~Hz})$, $7.67(\mathrm{~d}, 2 \mathrm{H}, 2 \mathrm{CH}=, \mathrm{Ar}, J=9.2 \mathrm{~Hz}), 9.60(\mathrm{~s}, 1 \mathrm{H}, \mathrm{NH}) ;{ }^{13} \mathrm{C}$ NMR (100 MHz, DMSO- $\left.d_{6}\right) \delta: 17.1\left(\mathrm{~N}\left(\mathrm{CH}_{2}\right)_{2}\left(\mathrm{CH}_{2}\right)_{2} \mathrm{CH}_{2}\right)$, $24.63\left(\mathrm{~N}\left(\mathrm{CH}_{2}\right)_{2}\left(\mathrm{CH}_{2}\right)_{2} \mathrm{CH}_{2}\right), 40.23 \mathrm{~N}\left(\mathrm{CH}_{2}\right)_{2}\left(\mathrm{CH}_{2}\right)_{2} \mathrm{CH}_{2}$, $64.0(2 \mathrm{C}-\mathrm{CN}), 110.8,114.2(2 \mathrm{CN}), 119.9(2 \mathrm{CH}=, \mathrm{Ar}), 125.5$ $(\mathrm{C}-\mathrm{Cl}), \quad 129.1 \quad(2 \mathrm{CH}=$, Ar $), 140.3(\mathrm{C}-\mathrm{NH}, \mathrm{Ar}), 147.0$ $(\mathrm{N}-\mathrm{C}-\mathrm{N}), \quad 150.8 \quad(\mathrm{~N}-\mathrm{C}-\mathrm{NH}), \quad 156.0 \quad\left(\mathrm{C}-\mathrm{NH}_{2}\right), \quad 162.7$ $\left(\mathrm{C}=\mathrm{C}-\mathrm{N}\right.$ ). DIMS found $\mathrm{m} / z$ : 392.20 (calc. for $\mathrm{C}_{19} \mathrm{H}_{17} \mathrm{ClN}_{8} \mathrm{M}^{+}$ requires 392.13).

\subsubsection{Preparation of 2-(4-Chlorophenylamino)-5, 7-Dimethylpyrazolo [1,5-a] Pyrimidine-3-Carbonitrile (6)}

Pyrazolo $[1,5-a]$ pyrimidine 6 were prepared according to the literature procedure $[13,14]$ as follows: To a mixture of 5-aminopyrazole $3(0.467 \mathrm{~g}, 2 \mathrm{mmol})$ and acetyl acetone $(0.225 \mathrm{~g}, 2 \mathrm{mmol})$ in DMF $(20 \mathrm{~mL})$ and three drops of glacial acetic acid were added. The resulting mixture was refluxed for $5 \mathrm{~h}$, and allowed to cool at room temperature and then the reaction mixture was poured into crushed-ice, and the separated solid was filtered off, dried well and crystallized from EtOH:DMF to give compound 6.

Yield, 23\%; yellow crystals; mp $319-320^{\circ} \mathrm{C}$; IR $\left(\mathrm{KBr}, \mathrm{cm}^{-1}\right)$ v: $3304(\mathrm{NH}), 3097(\mathrm{CH}-\mathrm{Ar}), 2222(\mathrm{CN}), 1596(\mathrm{C}=\mathrm{C} / \mathrm{C}=\mathrm{N})$; ${ }^{1} \mathrm{H}$ NMR (400 MHz, DMSO- $\left.d_{6}\right) \delta: 2.52\left(\mathrm{~s}, 3 \mathrm{H}, \mathrm{C}=\mathrm{C}-\mathrm{CH}_{3}\right)$, $2.66\left(\mathrm{~s}, 3 \mathrm{H}, \mathrm{N}=\mathrm{C}-\mathrm{CH}_{3}\right), 7.02(\mathrm{~s}, 1 \mathrm{H}, \mathrm{CH}), 7.33(\mathrm{~d}, 2 \mathrm{H}, \mathrm{Ar}$, $J=10.4 \mathrm{~Hz}), 7.76$ (d, 2H, Ar, $J=10.4 \mathrm{~Hz}), 9.61$ (s, 1H, $\mathrm{NH}-\mathrm{Ar}) ;{ }^{13} \mathrm{C} \quad \mathrm{NMR} \quad\left(100 \mathrm{MHz}, \quad \mathrm{DMSO}-d_{6}\right): \quad \delta \quad 17.1$ $\left(\mathrm{C}=\mathrm{C}-\mathrm{CH}_{3}\right), 24.6\left(\mathrm{~N}=\mathrm{C}-\mathrm{CH}_{3}\right), 67.6(\mathrm{C}-\mathrm{CN}), 110.8(\mathrm{C}=\mathrm{CH})$, $114.2(\mathrm{CN}), 119.9(2 \mathrm{CH}, \mathrm{Ar}), 125.3(\mathrm{C}-\mathrm{Cl}), 129.1(2 \mathrm{CH}$, Ar), $140.3(\mathrm{C}-\mathrm{NH}, \mathrm{Ar}), 147.1\left(=\mathrm{C}-\mathrm{CH}_{3}\right), 150.9(\mathrm{~N}-\mathrm{C}-\mathrm{N}=)$, $156.0(\mathrm{HN}-\mathrm{C}=\mathrm{N}), 162.8\left(\mathrm{~N}=\mathrm{C}-\mathrm{CH}_{3}\right)$; DIMS found $\mathrm{m} / \mathrm{z}$ : 297.70 (calc. for $\mathrm{C}_{15} \mathrm{H}_{12} \mathrm{ClN}_{5} \mathrm{M}^{+}$requires: 297.74).

requires: 310.05$)$.

\subsection{Antibacterial and Antifungal Evaluations}

Some of the selected synthesized compounds were evaluated for their antibacterial and antifungal activities using the agar diffusion technique [15] to determine which antibiotic (sample given) are most successful in treating bacteria or fungal infections. The response (sensitivity/resistance) of microbes against antimicrobial compounds various to each other. Microbes used in this test are: three bacterial [Staphylococcus aureus S276, Staphylococcus epidermidis S276, and Pseudomonas aeruginosa 15442] and two fungi: [Aspergillusbrasiliensis ATCC 1640 and Aspergillusniger UPMC 393]. The test is carried out by placing $6 \mathrm{~mm}$ diameter of paper disc containing antibiotic onto a plate which microbes are growing. The microbe culture is standardized to 0.5 McFarland standards which is approximately $10^{8}$ cells. Not more than 6 discs should be placed on the same agar plate. Streptomycin standard are used for each bacteria and Nystatin standard are used for fungi. The plates are inverted and incubate at $30-37^{\circ} \mathrm{C}$ for $18-24$ hours, $24-48$ or until sufficient growth has occurred. After incubation, each plate is examined. The diameters of the zones of complete inhibition (as judged by the unaided eye) are measured, including the diameter of the disc. Zones are measured to the nearest whole millimeter, using sliding calipers or a ruler, which is held on the back of the inverted Petri plate.

\subsection{Cytotoxicity Assay}

Some of the selected synthesized compounds were also tested against human breast adenocarcinoma (MCF-7) cell lines by using the MTT assay. Human MCF-7 breast adenocarcinoma cell line was procured from ATCC. The cells were cultured in a humid environment at $37^{\circ} \mathrm{C}$ and $5 \% \mathrm{CO}_{2}$ as a monolayer in DMEM (Dulbecco's Modified Eagles Medium; US Biological) supplemented with 10\% FBS (Fetal Bovine Serum; Bioclot) and 1\% penicillin/streptomycin (Invitrogen). Cells were grown up to $85-90 \%$ confluence and harvested using $0.25 \%$ trypsin/EDTA solution before sub-cultured onto 96-well plates. Cells were then treated with different compounds at a final concentration ranging from 0.47-30 $\mu \mathrm{g} / \mathrm{mL}$ for $24 \mathrm{hrs}$. Stock solutions were prepared in dimethylsulfoxide (DMSO) and stored at $20^{\circ} \mathrm{C}$ until used. The 3-(4, 5-dimethylthiazol-2-yl)-2, 5-diphenyl tetrazolium bromide (MTT) colorimetric assay developed [16] with modification was used to screen the cytotoxic activity of compounds. Briefly, $100 \mu$ l of the MCF-7 cells ( 1 x 105 cells $/ \mathrm{mL}$ ) were subculture onto sterile flat-bottomed 96 well plates and exposed to 7 different concentrations (30.00, 15.00, $7.50,3.75,1.87,0.93$ and $0.47 \mu \mathrm{g} / \mathrm{mL}$ ) of each compound for $24 \mathrm{~h}$. After the completion of Incubation in $37^{\circ} \mathrm{C}, 5 \% \mathrm{CO}_{2}$ incubator, $20 \mu \mathrm{L}$ of MTT reagent (Invitrogen) in $5.0 \mathrm{mg} / \mathrm{mL}$ phosphate buffered saline (PBS) was added to each well and further incubated for $3 \mathrm{~h}$ at $37^{\circ} \mathrm{C}, 5 \% \mathrm{CO}_{2}$ incubator. MTT solution was then removed before $100 \mu \mathrm{L}$ of DMSO (Sigma Aldrich) were added to each well and mix thoroughly to dissolve the blue formazan crystals. Further incubation was carried out for $20 \mathrm{~min}$. Finally, the optical density (OD) of each well was measured on ELISA reader at $570 \mathrm{~nm}$ (test wavelength) and $630 \mathrm{~nm}$ (reference wavelength). This cytotoxixity test was performed in two independent experiments, each time in triplicate. The percentage of cytotoxicity compared to the untreated cells was determined. The percentage of viability against each compound concentration were plotted to determine the $\mathrm{CC}_{50}$ value (the concentration at which $50 \%$ cell proliferation is inhibited). 
The percentage of cells viability was calculated in relative with the number of viable cells as a percentage of control by defining the absorbance at $570 \mathrm{~nm}$ for the control as $100 \%$.

\section{Results and Discussions}

\subsection{Chemistry}

The 5-amino-3-[4-chlorophenylamino]-1H-pyrazole-4carbonitrile intermediate 3 was prepared from<smiles>C[SH](C)(C)=C(C#N)C#N</smiles><smiles>CC(Nc1ccc(Cl)cc1)=C(C#N)C#N</smiles>

cyclocondensation of respective $\alpha, \alpha$-dicyanoketene- $N, S$ acetal 2-[(4-chlorophenylamino)(methylthio)methylene] malononitrile $2 \mathrm{a}$ with hydrazine hydrate under reflux in ethanol for four hours (Figure 1). The starting material 2a was prepared via the reaction of 2-[bis(methylthio) methylene]malononitrile 1 with an aromatic amine of $p$ choroaniline under reflux in ethanol in the presence of balloon of nitrogen gas for one week.

Figure 1. Synthesis of 5-aminopyrazole 3.

The chemical structure of the compound 3 was established on the basis of its spectral data. IR spectrum of 3 showed bands at $v 3430,3254 \mathrm{~cm}^{-1}$ for $\mathrm{NH}$ and $\mathrm{NH}_{2}$ groups. The $\mathrm{NH}_{2}$ protons in ${ }^{1} \mathrm{H}$ NMR spectrum were at $\delta 6.30 \mathrm{ppm}$, whereas the two singlet signals at $\delta 8.54$ and $11.19 \mathrm{ppm}$ assignable to the respective ArNH and cyclo-NH protons. The ${ }^{13} \mathrm{C}$ NMR spectrum was characterized by signals at $\delta 151.2$ and 153.5 ppm assigned to respective aromatic carbons of $\mathrm{NH}-\mathrm{C}=\mathrm{N}$ and $\mathrm{C}-\mathrm{NH}_{2}$. In addition, signals between $\delta 118.2-142.2 \mathrm{ppm}$ assigned to the other carbons of aromatic rings.
The above mentioned 5-aminopyrazole 3 was used as intermediates for the synthesis of new pyrazolo[1, 5-a] pyrimidines and pyrazolo[5, 1-c] $[1,2,4]$ triazines. Thus, condensation of 3 with ketene-S,S-acetals of 2-[bis (methylthio)methylene]malononitrile and ethyl 2-cyano-3, 3bis[methylthio]acrylate in refluxing ethanol containing a catalytic amount of triethylamine (TEA) afforded the corresponding pyrazolo[1, 5-a]pyrimidines 4a-b (Figure 2). The starting material ketene-S,S-acetals were prepared according to the previously reported procedure [17].
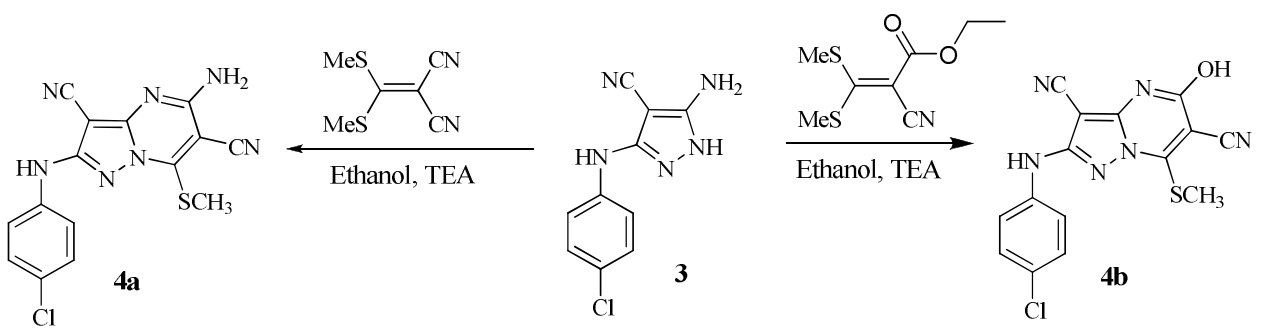

Figure 2. Synthesis of pyrazolo [1, 5-a] pyrimidines $4 a$ and $4 b$.

On the other hand, the reaction of 5-aminopyrazole 3 with $\alpha, \alpha$-dicyanoketene- $N, S$-acetals of 2-[(4-chlorophenylamino) (methylthio)methylene]malononitrile 2a, 2-[methylthio (morpholino) methylene]malononitrile 2b, and 2-[methylthio (piperidin-1-yl)methylene]malononitrile 2c under same condition yielded respective pyrazolo $[1,5-a]$ pyrimidines $5 \mathrm{a}-$ c (Figure 3). The $\alpha, \alpha$-dicyanoketene- $N, S$-acetals 2 b-c were prepared via the reaction of 2-[bis (methylthio) methylene] malononitrile 1 with an appropriate cyclic secondary amines of morpholine and pipyridine in refluxing ethanol according to the previously reported procedure [20]. The proposed structures of the compounds $5 \mathrm{a}-\mathrm{c}$ were established on the basis of spectral data (see Experimental).
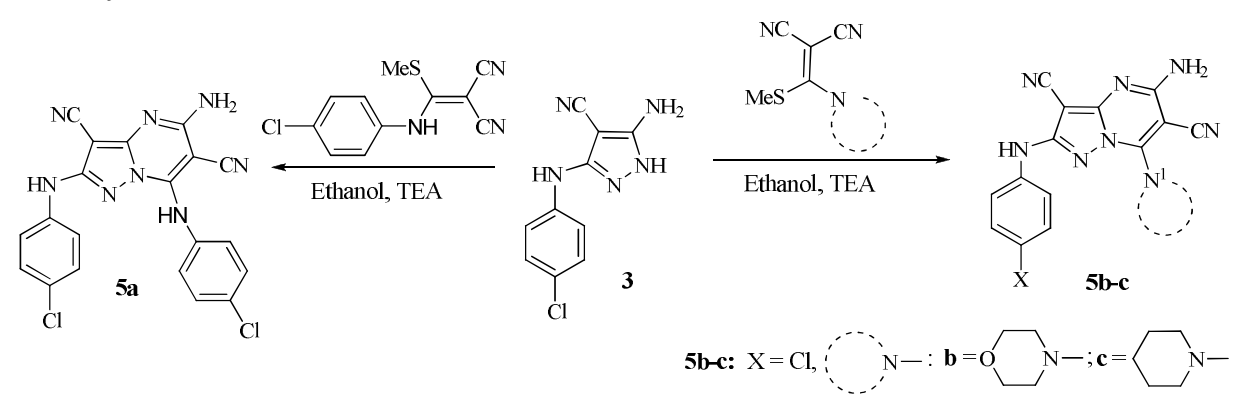

Figure 3. Synthesis of pyrazolo [1, 5-a] pyrimidines $5 a-c$. 
The proposed mechanism for the formation of pyrazolo[1,5-a]pyrimidines $4 \mathrm{a}-\mathrm{b}$ and $5 \mathrm{a}-\mathrm{c}$ is similar to that for the formation of 5-aminopyrazole 3, except that the final step in the former involves 1, 3-hydrogen migration rather than 1, 5-hydrogen migration in the latter (Figure 4).

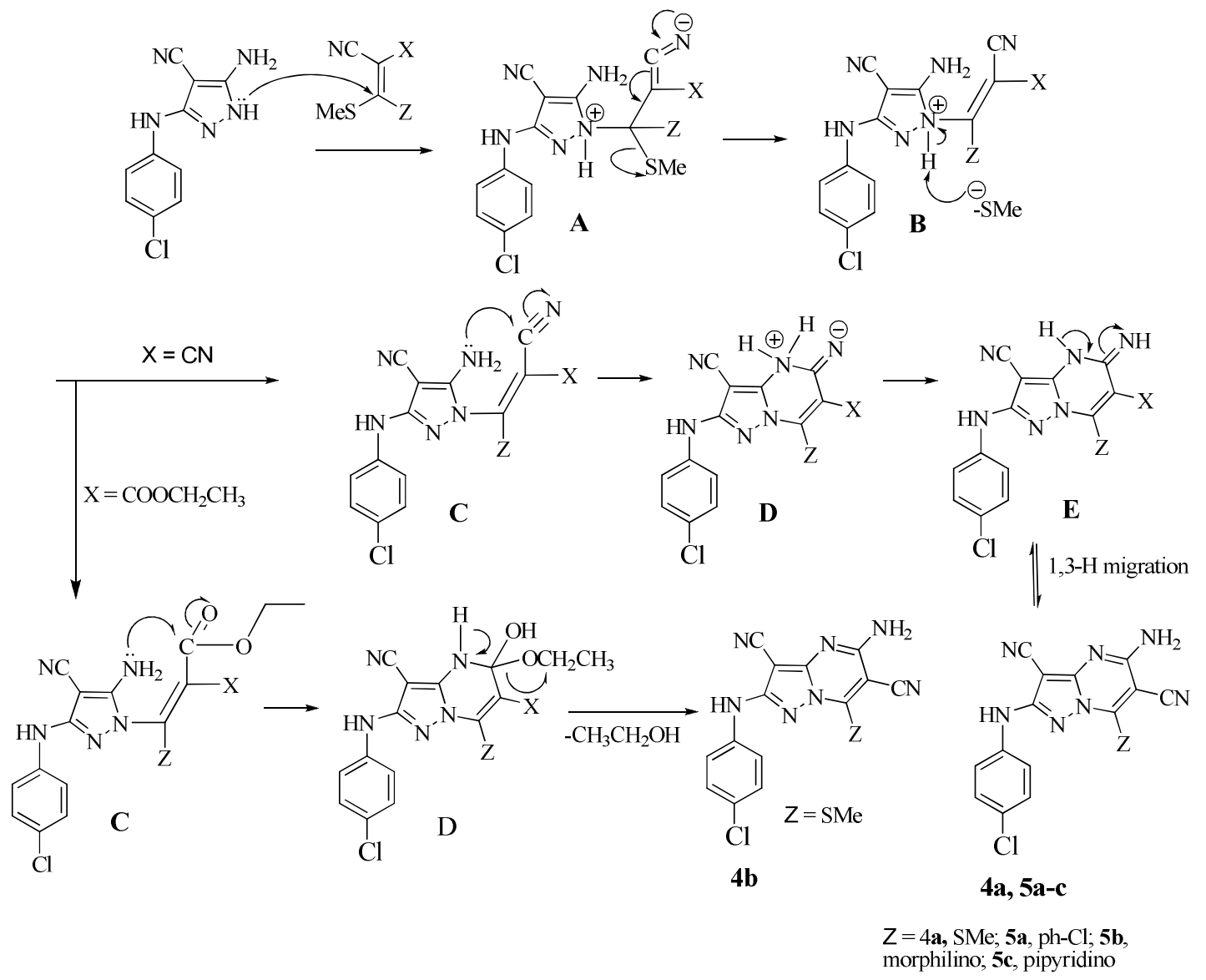

Figure 4. Mechanism for formation of pyrazolo [1, 5-a] pyrimidines $4 a-b$ and $5 a-c$.

We also attempted a direct synthesis of pyrazolo[1, 5- $a]$ pyrimidine 6 by treating 5 -aminopyrazole 3 with respective pentane-2, 4-dione in refluxing dimethylformamide (DMF) containing a catalytic amount of glacial acetic acid (Figure $5)$. The structure of the pyrazolo $[1,5-a]$ pyrimidine 6 was elucidated on the basis of its spectral data. The characteristic absorption band in the IR spectrum of 6 is at $v 3304 \mathrm{~cm}^{-1}$ for $\mathrm{NH}$ stretching vibration. The ${ }^{1} \mathrm{H}$ NMR spectrum of compound 6 displayed singlet signals at $\delta 2.50$ and $2.66 \mathrm{ppm}$, which correspond to six protons of two methyl groups of $\mathrm{CH}_{3}$ and $\mathrm{COCH}_{3}$. The structure of the isolated product was supported by its direct infusion mass spectrometry (DIMS) result, which showed molecular ion corresponding to the molecular formula. The DIMS of 2-(4-chlorophenylamino)5, 7-dimethylpyrazolo $[1,5-a]$ pyrimidine-3-carbonitrile 6 showed a molecular ion at $m / z=297.70$ which corresponds to the molecular formula $\mathrm{C}_{15} \mathrm{H}_{12} \mathrm{ClN}_{5}$ (297.74).<smiles>N#Cc1c(Nc2ccc(Cl)cc2)n[nH]c1N</smiles><smiles>CCCCCCC(C)=O</smiles>

Figure 5. Synthesis of pyrazolo [1, 5-a] pyrimidine 6.

The mechanism for the formation of 6 is shown in Figure 6. The conversion involves three major steps, as follows: (i) nucleophilic attack of the $\mathrm{NH}_{2}$ group from 5-aminopyrazole 3 onto the carbonyl group of acetylacetone, by releasing water molecule, to form intermediate imine A; (ii) intramolecular cyclization occurs by a nucleophilic attack of the $\mathrm{NH}$ of pyrazole onto the other carbonyl group to form an intermediate adduct B; and (iii) dehydration in B produces 6 . 
<smiles>CC(=O)CC(C)=O</smiles><smiles></smiles>

Figure 6. Mechanism for formation of pyrazolo [1, 5-a] pyrimidine 6.

The structure of compound 6 was identified by X-ray diffraction analysis. The molecular structure and the numbering scheme are presented in Figure 7. Suitable crystals of 6 were grown by slow evaporation from DMSO solution. The crystal data and structure refinement results for 6 are given in Table 1. Compound 6 crystallized in a monoclinic system with space group of $P 21 / n$. Selected bond distances and bond angles for 6 are given in Table 2. The bond lengths and angles of the new molecule are within in the normal ranges [18]. The phenyl ring $(\mathrm{C} 1-\mathrm{C} 6)$ is essentially planar with a maximum deviation of 0.001 (3) A, for atom $\mathrm{C} 1$. The maximum deviation in the pyrazole ring $\mathrm{N} 2 / \mathrm{N} 3 / \mathrm{C} 7 / \mathrm{C} 8 / \mathrm{C} 10$ in 6 is 0.000 (2) $\AA$, for atom N2. The dihedral angle between the mean planes of the pyrazole and the 4, 6-Dimethyl-1, 6-dihydro-pyridazine ring in 6 is 1.52 (14) ${ }^{\circ}$ (see Electronic Supplementary Information [19]). In crystal packing of compound 6 , the molecules are connected by weak $\mathrm{C}-\mathrm{H}^{\cdots \cdots} \mathrm{N}$ and $\mathrm{N}-\mathrm{H}^{\cdots} \mathrm{N}$ intermolecular hydrogen bonds forming one-dimensional chains along the $b$ axis (Figure 8).

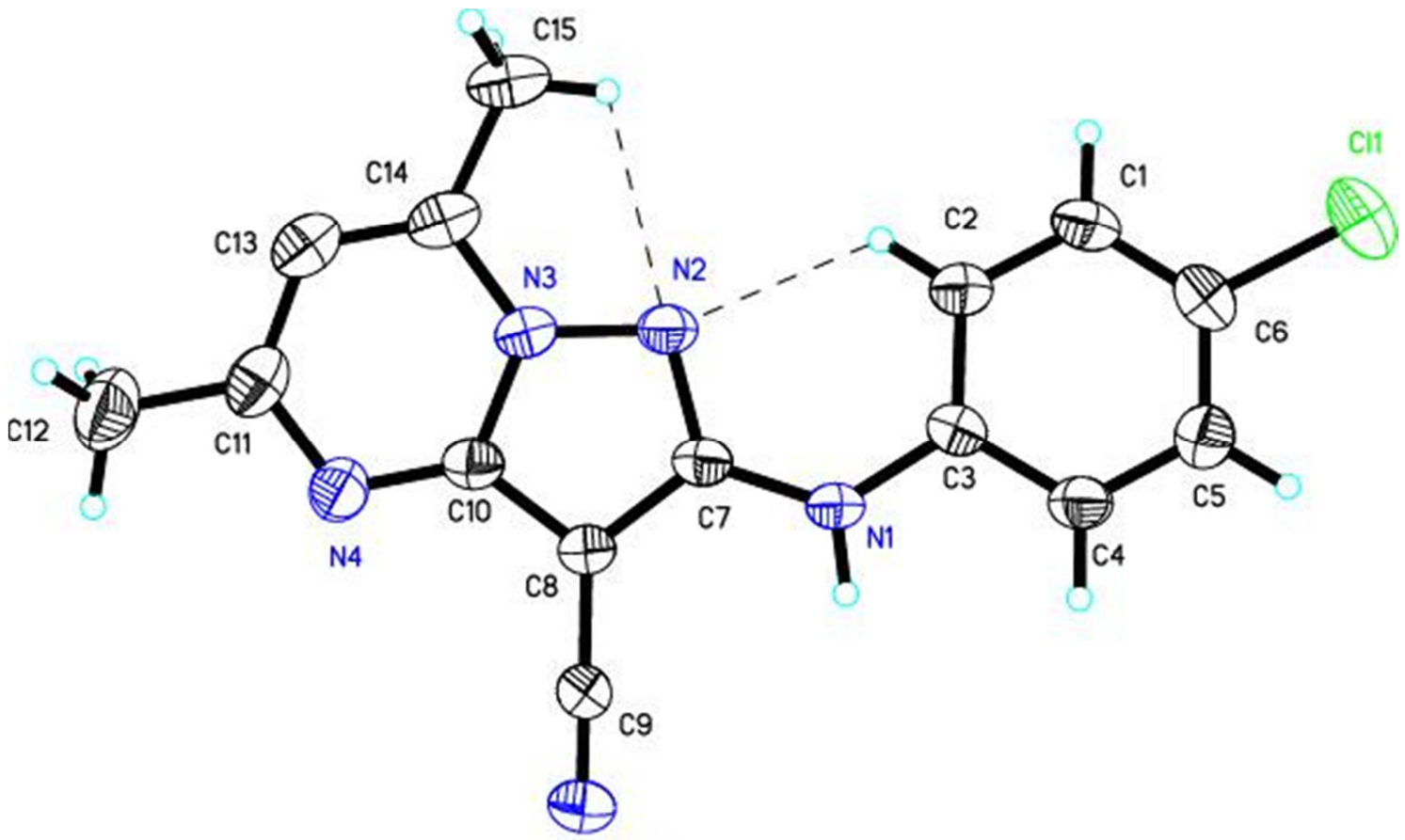

N5

Figure 7. The molecular structure of compound 6 with 50\% probability displacement ellipsoids with Dashed lines indicate hydrogen bonds. 


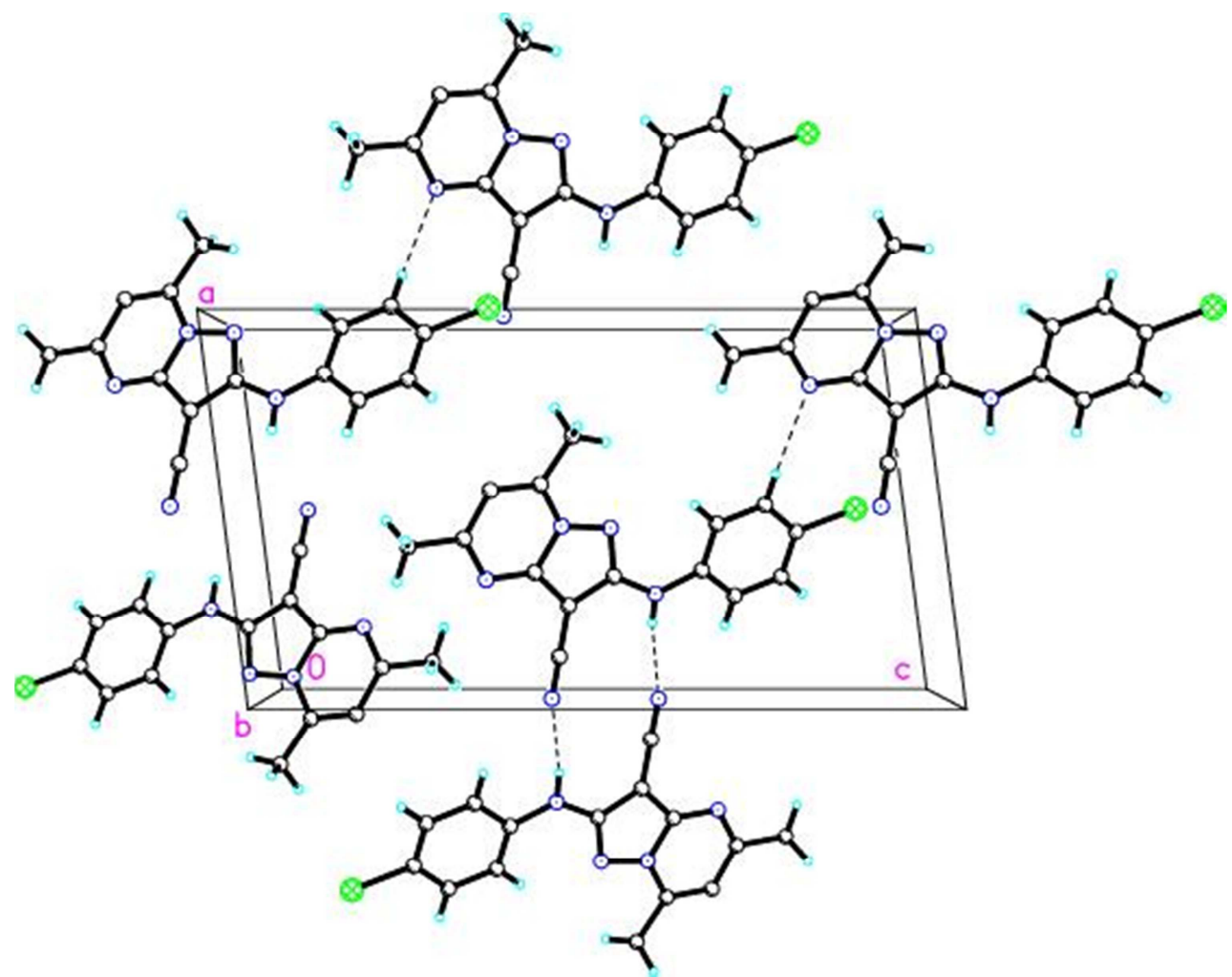

Figure 8. Packing diagrams of compound 6, viewed down the b axis. The dashed lines denote $C-H^{\cdots} N$ and $N-H{ }^{\prime \prime} N$ hydrogen bonds.

Table 1. Crystal data and structure refinement for 6 .

\begin{tabular}{llll}
\hline & Crystal 6 & & Crystal 6 \\
\hline Chemical formula & $\mathrm{C}_{15} \mathrm{H}_{11} \mathrm{Cl} \mathrm{N}_{5}$ & Absorption coefficient & $0.268 \mathrm{~mm}^{-1}$ \\
Formula weight & $296.74 \mathrm{~g} \mathrm{~mol}^{-1}$ & $\mathrm{~F}(000)$ & 612 \\
Colour & Yellowish & Theta range for data collection & $2.8-28.6\left(^{\circ}\right)$ \\
Crystal shape & Block & Reflections collected / unique & $49323,3625, R_{\text {int }}=0.098$ \\
Size mm & $0.31 \times 0.25 \times 0.35$ & Completeness to theta $=25.00$ & 71.023 \\
Temperature & $293 \mathrm{~K}$ & Max. and min. transmission & $T_{\min }=0.912, T_{\max }=0.936$ \\
Wavelength & $0.71073 \AA$ & Refinement method & Full-matrix least-squares on $\mathrm{F}^{2}$ \\
Crystal system & Monoclinic & Data/ restraints/ parameters & $3322 / 0 / 253$ \\
Space group & $P 21 / n$ & Goodness-of-fit on $\mathrm{F}^{2}$ & 1.10 Full-matrix least-squares on $\mathrm{F}^{2}$ \\
& $10.1362(6)$ & & \\
$a, b, c(\AA) ;$ & $7.8459(5)$ & Final R indices [I $>2 \sigma(\mathrm{I})]$ & $R=0.0839, w R=0.2002$ \\
& $18.0725(11)$ & & \\
$\alpha, \beta, \gamma()^{\circ}$ & $90,97.268(3), 90$ & Largest diff. peak and hole & $-0.49 \&-0.66 \mathrm{e} \AA^{-3}$ \\
Cell volume & $1425.72(15)$ & Calculated density & $1.3825(1) \mathrm{g} \cdot \mathrm{cm}^{-3}$ \\
$\mathrm{Z}$ & 4 & & \\
\hline
\end{tabular}

Table 2. Selected bond lengths $(\AA)$ and bond angles $\left(^{\circ}\right)$ for 6.

\begin{tabular}{llll}
\hline Bond & Bond length $(\AA)$ & Bond & Bond angle $\left(^{\circ}\right)$ \\
\hline C11-C6 & $1.746(3)$ & $\mathrm{C} 3-\mathrm{N} 1-\mathrm{C} 7$ & $129.5(2)$ \\
N1-C3 & $1.401(3)$ & $\mathrm{N} 3-\mathrm{N} 2-\mathrm{C} 7$ & $103.6(2)$ \\
N1-C7 & $1.362(3)$ & $\mathrm{C} 10-\mathrm{N} 3-\mathrm{C} 14$ & $121.6(2)$ \\
N2-N3 & $1.375(3)$ & $\mathrm{C} 10-\mathrm{N} 4-\mathrm{C} 11$ & $116.0(2)$ \\
N4-C10 & $1.337(3)$ & $\mathrm{N} 1-\mathrm{C} 3-\mathrm{C} 4$ & $116.8(2)$ \\
C1-C6 & $1.364(4)$ & $\mathrm{C} 11-\mathrm{C} 6-\mathrm{C} 1$ & $120.5(2)$ \\
C7-C8 & $1.421(3)$ & $\mathrm{N} 1-\mathrm{C} 7-\mathrm{N} 2$ & $123.2(2)$ \\
C8-C9 & $1.411(4)$ & $\mathrm{C} 13-\mathrm{C} 14-\mathrm{C} 15$ & $125.8(3)$ \\
C13-C14 & $1.366(4)$ & $\mathrm{N} 4-\mathrm{C} 11-\mathrm{C} 13$ & $122.7(3)$ \\
C14-C15 & $1.488(4)$ & $\mathrm{N} 3-\mathrm{C} 14-\mathrm{C} 15$ & $118.4(3)$ \\
\hline
\end{tabular}

\subsection{Antibacterial, Antifungal Evaluations and Cytotoxicity Assay}

The antibacterial and antifungal activities results are listed in Table 3 . The results for the pyrazolo [1, 5-a] pyrimidines 
showed moderate against tested bacteria and fungi. Compounds $4 \mathrm{~b}$ and $5 \mathrm{~b}$ exhibited inhibitory activity against all bacteria tested.

Table 3. Inhibition zone (mean diameter of inhibition in mm) as a criterion of antibacterial and antifungal activities of the some newly synthesized compounds.

\begin{tabular}{|c|c|c|c|c|c|}
\hline \multirow{3}{*}{ Compound } & \multicolumn{5}{|c|}{ Inhibition zone $(\mathrm{mm})^{\mathrm{c}}$} \\
\hline & \multicolumn{3}{|c|}{ Antibacterial evaluation } & \multicolumn{2}{|c|}{ Antifungal evaluation } \\
\hline & $\begin{array}{l}\text { Staphylococcus } \\
\text { aureus } \mathbf{S} 276\end{array}$ & $\begin{array}{l}\text { Staphylococcus } \\
\text { eperdermidis } \mathbf{S} 273\end{array}$ & $\begin{array}{l}\text { Pseudomonas } \\
\text { aeruginosa } 15442\end{array}$ & $\begin{array}{l}\text { Aspergillusniger } \\
\text { UPМС } 393\end{array}$ & $\begin{array}{l}\text { Aspergillusbrasiliensis } \\
\text { ATCC16404 }\end{array}$ \\
\hline $4 \mathrm{a}$ & $10 \pm 0.56$ & $11 \pm 0.57$ & $11 \pm 0.57$ & $9 \pm 0.62$ & $8 \pm 0.57$ \\
\hline $5 b$ & $10 \pm 0.55$ & $11 \pm 0.58$ & $10 \pm 0.56$ & $7 \pm 0.58$ & $8 \pm 0.58$ \\
\hline 6 & $6 \pm 0.57$ & $8 \pm 0.57$ & $7 \pm 0.55$ & $8 \pm 0.58$ & $9 \pm 0.58$ \\
\hline${ }^{\mathrm{a}}$ Streptomycin & 20 & 23 & 27 & - & - \\
\hline bystatin & - & - & - & 20 & 23 \\
\hline
\end{tabular}

${ }^{\text {a }}$ Setreptomycin as reference drug for bacteria.

${ }^{\mathrm{b}}$ Nystatin as reference drug for fungi.

${ }^{\mathrm{c}}$ Values are mean inhibition zone $(\mathrm{mm}) \pm \mathrm{S}$. D of results done in triplicate.

$6 \mathrm{~mm}$ is the diameter of the disc

Cytotoxicity results of tested compounds are summarized in Table 4. The $\mathrm{CC}_{50}$ value was graphically obtained by plotting the percentage growth inhibition against the corresponding different concentrations of the test compound used. The $\mathrm{CC}_{50}$ values for compound $4 \mathrm{a}$ was found to be 7.5 $\mu \mathrm{g} / \mathrm{ml}$ (graphically represented in Figuer. 9) while the other three compounds namely $5 \mathrm{~b}, 5 \mathrm{c}$, and $6 \mathrm{CC}_{50}$ value of more than $30 \mu \mathrm{g} / \mathrm{ml}$. According to Chandrashekar et al [20], $\mathrm{CC}_{50}$ value of more than $20 \mu \mathrm{g} / \mathrm{ml}$ can be considered as non cytotoxic.

Table 4. Cytotoxicity $\left(C_{50}\right)$ of some selected compounds against Human MCF-7 cells.

\begin{tabular}{ll}
\hline Compounds & CC50 value $(\mu \mathrm{g} / \mathrm{ml})$ \\
\hline $4 \mathrm{a}$ & $7.5 \pm 2.04$ \\
$5 \mathrm{~b}$ & $>30$ \\
$5 \mathrm{c}$ & $>30$ \\
6 & $>30$ \\
\hline
\end{tabular}

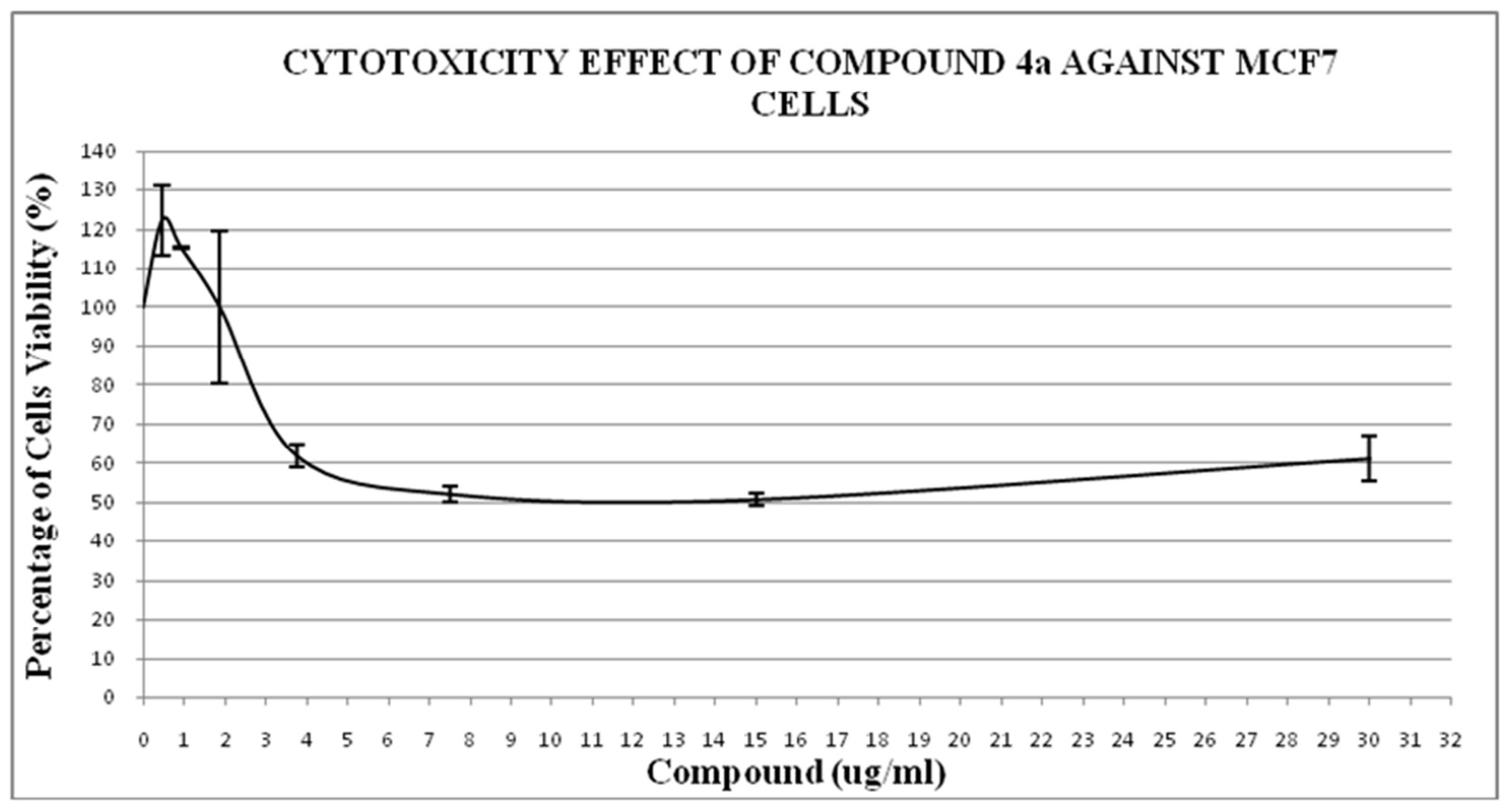

Figure 9. Cytotoxicity $\left(C C_{50}\right)$ of compound 4 a against Human MCF-7 cells by MTT assay.

\section{Conclusions}

We could successfully synthesized new a variety of pyrazolo $[1,5-a]$ pyrimidines from 5-aminopyrazole 3 . In this paper, we synthesized new pyrazolo $[1,5-a]$-pyrimidines $4 a-b, 5 a-c, 6$ by the reaction of 5-aminopyrazole 3 with respective 2-[bis (methylthio) methylene] malononitrile, ethyl 2-cyano-3, 3-bis [methylthio] acrylate, 2-[(4chlorophenylamino) (methylthio) methylene] malononitrile, 2-[methylthio (morpholino) methylene] malononitrile, 2[methylthio (piperidin-1-yl) methylene. All procedures for the synthesis of these compounds are very convenient due to the simple procedures, mild conditions, and moderate to high yields. Another advantage is that 5-aminopyrazole 3 was of 
the same starting material used for the preparation of all those compounds. Some of the prepared compounds shown unpromising antibacterial, antifungal activities and cytotoxicty. Only the compound $4 \mathrm{a}$ has cytotoxic and the $\mathrm{CC}_{50}$ value was found $7.5 \mu \mathrm{g} / \mathrm{mL}$.

\section{References}

[1] C. R. Petrie III, H. B. Cottam, P. A. McKernan, R. K. Robins, G. R Revankar. Synthesis and biological activity of 6azacadeguomycin and certain 3, 4, 6-trisubstituted pyrazolo $[3,4-d]$ pyrimidine ribonucleosides, J. Med. Chem. 28 (1985) 1010-1016.

[2] W. B. Parker, J. A. Secrist, W. R. Waud, Purine nucleoside antimetabolites in development for the treatment of cancer. Curr. Op. Invest. Drugs 5 (2004) 592-596.

[3] B. Zacharie, T. P. Connolly, R. Rej, G. Attardo, C. L. Penney, A short synthesis of 4-substituted 1-(hydroxyalkyl)-1Hpyrazolo $[3,4-d]$ pyrimidines, Tetrahedron, 52 (1996) 22712278.

[4] M. Mojzych; A. Rykowski, J. Wierzchowski, Pyrazolo [4, 3-e] $[1,2,4]$ triazines: Purine analogues with electronic absorption in the visible region, Molecules, 10 (2005) 1298-1306.

[5] G. A Bhat, J. G. Montero, R. P. Panzica, L. L. Worting, L. B. Towsend, pyrazolopyrimidine nucleosides. 12. Synthesis and biological activity of certain pyrazolo $[3,4-d]$-pyrimidine nucleosides related to adenosine. J. Med. Chem. 24 (1981) 1165-1172.

[6] J. L. Avila, M. A. Polegre, A. R. Avila, K. Robins, Action of pyrazolopyrimidine derivatives on american Leiishmania SPP Promastigotes, Comp. Biochem. Physiol. 83C (1986) 285289.

[7] J. Salimon, N. Salih, Synthesis, characterization and biological activity of some new 1,2, 4-triazine derivatives. Int. J. Pharm. Tech. Res. 2 (2010) 1041-1045.

[8] M. A. Elnagdi, M. R. H. Elmoghayer, G. H. Elgemeie, Chemistry of pyrazolopyrimidines, Adv. Heterocycl. Chem. 41 (1987) 320-367.

[9] M. A. Gouda, M. A. Berghot, A. I. Shoeib, A. M. Khalil, Synthesis and antimicrobial activity of new anthraquinone derivatives incorporating pyrazole moiety, Eur. J. Med. Chem. 45 (2010) 1843-1848.

[10] M. A. Gouda, A. I. Berghot, E. A. Ghada, A. M. Khalil, Synthesis and antimicrobial activities of some new thiazole and pyrazole derivatives based on $4,5,6,7-$ tetrahydrobenzothiophene moiety, Eur. J. Med. Chem. 45 (2010) 1338-1345.

[11] Wedad M. Al-Adiwish, M. I. M. Tahir, Siti-NoorAdnalizawati A., Siti Farah Hashim, Nazlina Ibrahim and W. A. Yaacob. 2013. Synthesis, Antibacterial Activity and Cytotoxicity of New Fused Pyrazolo [1, 5- $a$ ] pyrimidine and Pyrazolo [5, 1-c] $[1,2,4]$ triazine Derivatives from New 5Aminopyrazoles. European Journal of Medicinal Chemistry 64: 464-476.

[12] M. A. Elnagdi, M. R. H. Elmoghayer, G. H. Elgemeie, Chemistry of pyrazolopyrimidines, Adv. Heterocyclic Chem. 41 (1987) 320-367. J. D. Anderson, H. B. Cottam, S. B. Larson, L. D. Nord, G. R. Revankar, R. K. Robins, Synthesis of certain pyrazolo [3, 4-d] pyrimidin-3-one nucleosides, J. Heterocyclic Chem. 27 (1990) 439-453.

[13] Clinical and Laboratory Standards Institute, Performance Standards for Antimicrobial Disk Susceptibility Test. Approved Standard, ninth ed., CLSI, Wayne, PA, USA, 2006.

[14] Mosmann T. Rapid Colorimetric Assay for Cellular Growth and Survival: Application to Proliferation and Cytotoxicity Assays. Journal of Immunology Methods 1983; 65: 55-63.

[15] F. H. Allen, O. Kennard, D. G. Watson, L. Brammer, A. G. Orpen, R. J. Taylor, Table of bond lengths determined by Xray and neutron diffraction. Part 1 . Bond lengths in organic compounds, Chem. Soc. Perkin Trans. 2. (1987), S1 1 S19

[16] CCDC 1033262 contains the supplementary crystallographic data for this paper. These data can be obtained free of charge via www.ccdc.cam.ac.uk/conts/retrieving.html (or from the CCDC, 12 Union Road, Cambridge CB2 1EZ, UK, fax: +44 1223 336033, e-mail: deposit@ccdc.cam.ac.uk).

[17] Chandrashekar, G. J., Gopal, M. And Byregowda, S. M. 2011. Cytotoxic activity of Tragia involucrate. Linn. Extract. American-Eurasian Journal of Toxicological Sciences. 3 (2): 6769 .

[18] F. H. Allen, O. Kennard, D. G. Watson, L. Brammer, A. G. Orpen, R. J. Taylor, Table of bond lengths determined by Xray and neutron diffraction. Part 1. Bond lengths in organic compounds, Chem. Soc. Perkin Trans. 2. (1987), S1 1 S19

[19] CCDC 1033261 contains the supplementary crystallographic data for this paper. These data can be obtained free of charge via www.ccdc.cam.ac.uk/conts/retrieving.html (or from the CCDC, 12 Union Road, Cambridge CB2 1EZ, UK, fax: +44 1223 336033, e-mail: deposit@ccdc.cam.ac.uk).

[20] Chandrashekar, G. J., Gopal, M. And Byregowda, S. M. 2011. Cytotoxic activity of Tragia involucrate. Linn. Extract. American-Eurasian Journal of Toxicological Sciences. 3 (2): 6769. 